Jain HC, Horwitz FM, Wilkin CL, Employment Equity in Canada and South Africa: A Comparative Review, The International Journal of Human Resource Management, Volume 23, 2012, Issue 1, pages 1-17

\title{
Employment Equity in Canada and South Africa: A Comparative Review
}

\section{Harish C. Jain, McMaster University; Frank Horwitz, Cranfield University; Christa Wilkin, McMaster University}

\begin{abstract}
The South African government has sought to redress the historical legacy of workplace discrimination by introducing the Employment Equity Act (1998), which was largely modeled on the Canadian Employment Equity Act. Although there is very little comparative information between South Africa and Canada, we fill this gap by reviewing the literature in both countries, highlighting common features of the legislation, discussing the effectiveness of legislation in both countries, as well as the progress made by the designated groups covered by the legislation. This paper provides a background on the rationale for employment equity and associated human resource management policies in both Canada and South Africa. The analysis is largely based on institutional theory of organizations. Our evaluation provides overall conclusions for policy makers and organizational leaders, taking into consideration socio-historical, political, and demographic differences between the jurisdictions. Issues include top management commitment, organizational culture, black economic empowerment, and diversity policies and practice.
\end{abstract}

Keywords: Canada; comparative; employment equity; institutional theory; South Africa 


\section{Introduction}

Even though Canada and South Africa have different historical trajectories, both countries are members of the Commonwealth, have parliamentary democracies, and have adopted policies that involve government intervention for the prevention and elimination of unfair employment discrimination against racial groups, women, and persons with disabilities. Each country has developed a shared approach to employment equity. The construct of employment equity forms the basis of the South African Employment Equity Act (1998), which is mainly based on the Canadian jurisdiction, although the Act has also borrowed from other jurisdictions. Although the Canadian legislation has greatly influenced the South African legislation, there is very little comparative information on employment equity in South Africa and Canada. A comparative paper is important to be able to determine how effective the legislation has been in both countries. It is also important given the influence that tenets and principles of the Canadian employment equity regime have had on the evolution of the South African one. The paper shows how regulatory systems pertaining to human resource management issues reveal elements of convergence over time.

The purpose of the paper is to examine developments in employment equity. The paper provides an overview of the similarities and differences of the Canadian and South African employment equity frameworks, and outlines the demographics of the labour markets in the two countries. The main features of the employment equity legislative framework in Canada and South Africa are analyzed using neo-institutional theory. Within the framework of institutional theory, this paper seeks to provide a comparative analysis of goals and outcomes of two nominally similar regulatory systems, while considering historical differences but similar organizational challenges in respect to effective implementation. Important in this regard is the acceptance in South Africa of a regulatory system 'borrowed and bent' from others particularly 
the Canadian system. Much for the nomenclature and terminology of the two systems are similar. We discuss the effectiveness of the legislation, including certain strengths and weaknesses of the respective legislations, with a particular focus on the developments in employment equity. We first provide a background on employment equity legislation in both countries, then compare and contrast policies and practices, and assess the progress thus far. A conclusion follows with propositions for consideration by South African and Canadian policymakers and managers. These propositions will assist policy makers and managers as they strive to continue to develop proactive policies and new initiatives to accommodate designated groups, which include racial groups such as Africans, Coloureds, and Indians in South Africa, visible minorities and Aboriginals in Canada, and women and persons with disabilities in both South Africa and Canada.

\section{Background on employment equity in Canada}

Since the early 1960s, Canada has had human rights statutes across all jurisdictions to prevent and eliminate discrimination on numerous prohibited grounds such as race, gender, and disability, as well as provisions in these statutes to allow employers to mount voluntary employment equity programs (usually called special programs) for disadvantaged groups. At the

federal level, the government has had employment equity legislation since 1986. This legislation was amended in 1995 and extended to almost all federal government departments and agencies; the latter were originally excluded from this legislation in 1986. The federal government has also had the Federal Contractors Program since 1986, which applies to large provincially regulated employers who supply goods and services to the federal government's departments and agencies. The Employment Equity Act covers 617 employers in the public and private sectors, and over 900 federal contractors; the legislation applies to 698,210 employees in the private sector and 368,399 employees in the public sector (Human Resources and Social Development Canada, 
2008). The focus in Canada has been primarily on minority groups, which is an important point of departure from the South African model where the focus is based on a historically and demographically different trajectory.

\section{Background on employment equity in South Africa}

In the 1990s and 2000s, the post-Apartheid state in South Africa enacted some of the most progressive legislative measures, which included the Labour Relations Act (1995), Employment Equity Act (1998), Skills Development Act (1998), and Promotion of Equality Act (1999). South Africa has patterned its Employment Equity Act and part of its Constitution such as Section 9(2) of the Constitutional Bill of Rights after Canada. Another important piece of legislation is the Broad-Based Black Economic Empowerment Act (2003), which was enacted to provide Black people with economic opportunities to control, manage, and own the South African economy, in addition to significantly reducing income inequalities (Department of Trade \& Industry, 2003). Whereas employment equity legislation focuses mainly on employment opportunity redress in workplace practices, the Broad-Based Black Economic Empowerment Act espouses earlier attempts of the Reconstruction and Development Program to transfer management, control, and ownership to Black people (Black Economic Empowerment Commission, 2001; Mbabane, 2007).

\section{Theoretical framework}

We base our analysis largely on arguments from institutional theory (DiMaggio \& Powell 1991, Meyer \& Rowan 1991), which has come to be known as "new institutionalism" or neoinstitutionalism. The neo-institutional framework focuses on the role that external social forces play in shaping organizational actions. A prime assumption of neo-institutional theory is that organizations seek legitimacy from the external world. Scott (1998) identifies the three primary mechanisms that might impact firms' actions. Regulative forces are those associated with 
specific laws and governmental rules. Firms are responsive to regulative forces because the failure to do so puts organizations or their managers at risk of legal sanctions. In the context of this paper, Employment Equity Acts represent a significant regulative force and firms risk legal sanctions by not complying with the law. For this reason, regulative forces play an especially important part in shaping how organizations respond to employment equity. Normative forces are a second mechanism that mainly arise from professional standards. Here human resource managers might be expected to respond to the norms and expectations of their profession regarding appropriate employment equity actions. Finally, there are mimetic forces, which suggest that organizations imitate similar organizations as a matter of dealing with environmental uncertainty. The impact of these forces is important because these forces institutionalize certain ways of doing things, which become "taken for granted" across populations of organizations. Organizations respond to institutionalized rules, norms, and beliefs, so that they emulate one another, leading to organizational isomorphism. Institutional theory has been used in a wide range of studies of organizational action (e.g., Jaffee, 2001) and can lead to an understanding of the propensity of firms to discriminate in employment decisions (e.g., Blum, Fields, and Goodman, 1994).

According to institutional theory, organizational responses to institutional pressures depend on factors such as the degree of legal coercion and environmental uncertainty (Oliver, 1991). The Employment Equity Act authorizes the Minister of Labour in Canada to fine employers with monetary penalties to a maximum of $\$ 10,000$ per day and $\$ 50,000$ per calendar year. The South African Employment Equity Act outlines fines from R500,000 to R900,000 based on whether or not previous contraventions were made over a specific period of time. In the case of the Canadian Employment Equity Act, the newer enforcement mechanisms would be viewed as increasing the costs of non-compliance, yet these costs might not be sufficient to 
generate greater compliance with employment equity goals; in fact, few firms have actually been subject to audits and other enforcement actions. Consequently, enforcement mechanisms might be viewed as weak by employers, thus weakening motivation to comply with the law.

Oliver (1991) suggests that organizational compliance to institutional pressures is also affected by the degree of environmental uncertainty. The requirement that firms submit annual reports that are publicly available in Canada (posted on the Internet) would presumably reduce the option of a firm hiding behind a veil of uncertainty. However, the online documentation is somewhat complex and perhaps all but the largest firms might evade public scrutiny. In South Africa, firms are required to submit annual reports and are subject to monitoring by the Employment Equity Commission and the South African Department of Labour.

Similar to the Canadian Employment Equity Act, the South African Employment Equity Act provides employers with written undertakings when the Act has been breached. Failure to comply with these written undertakings from labour inspectors results in compliance orders. If compliance orders are not adhered to, the Director-General of the Department of Labour can order employers to comply through the Labour Court (Department of Labour, 2007). The actions of the Labour Minister have been reported in major newspapers (e.g., Business Day), which reported on the review of six major employers in 2007. Although the actions of Labour Ministers have been publicized, some 26 employers were still found to be in breach of law in 2008 .

It is under conditions of high uncertainty that firms are more apt to imitate one another (Oliver, 1991). So any ambiguity regarding employment equity compliance might allow firms to follow long-established societal norms promoting discrimination. It might be, for example, that, given uncertainty, at least some firms could engage in manipulative strategies intended to convince regulators that they are moving toward employment equity goals without any real progress taking place. Oliver (1991) identifies a number of other environmental factors (e.g., 
interconnectedness) that might promote or reduce firm compliance with institutional expectations. While in this paper, we are not in a position to test these moderating influences directly, it is not a foregone conclusion that changes in the employment equity legislation in both countries would favourably impact achieving employment equity goals.

\section{Common features of the Canadian and South African employment statutes}

Both jurisdictions have the construct of employment equity as a common feature. There are eight common employer obligations under the Canadian and South African employment equity statutes, illustrated in Table 1. As noted above, the South African is primarily based on the Canadian jurisdiction, and as a result, the statutes are highly similar. Both statutes aim to promote equal opportunities for disadvantaged groups, however the composition of the groups differ because of different historical and demographic trajectories. Both statutes address the need for employers to identify and eliminate job barriers, develop short-term and long-term employment equity plans, consult with employee representatives or bargaining agents, and formulate numerical goals and timetables. Employers are also required to keep records relating to employee 'stock and flow' but they are not required to adopt measures that might cause undue hardship.

Insert Table 1 about here

\section{Diversity and changing market profiles}

Demographic data relating to racial diversity in Canada's population and workforce reflects increasing change. According to 2001 Census data, the visible minority population has almost tripled within two decades and grew from $4.7 \%$ in 1981 to $13.4 \%$ in 2001 (Statistics Canada, 2001). By 2017, racial minorities are expected to represent one in five people in Canada's available workforce; in major Canadian cities, the representation of visible minorities 
in the labour force will be closer to half (Immen, 2007). Women represented $50.9 \%$ of the population, Aboriginals or 'First Nations people' constituted 3.3\%, and persons with disabilities accounted for 5.1\% in 2001 (Statistics Canada, 2001). Table 2 illustrates the representation of designated groups in both Canada and South Africa from 1996 to 2001.

Insert Table 2 about here

According to the 2001 South African Census, the population was approximately 45 million with approximately half (52\%) of the total population estimated to be female. According to the Statistics South Africa's Labour Force Survey, 4.3 million people were unemployed in 2007, or some $25.5 \%$ of the economically active population (South African Institute of Race Relations, 2008). Table 2 outlines the composition of the South African population, which is $52.2 \%$ female (as noted above), 79.0\% African, 8.9\% Coloured, 2.5\% Indian, $5.9 \%$ persons with disabilities and 9.6\% Whites. Even though the composition shows that Blacks (i.e., Africans, Coloured people, and Indians) account for $90.4 \%$ of the population, the former Apartheid regime created inequality for Blacks to access education, skills, professional, and managerial work. Job discrimination in South Africa was institutionalized by laws under the Mines and Works Act and the Industrial Conciliation Act of 1904 and 1952 respectively that included job reservation clauses and restricted access to skilled jobs in order to preserve them for White employees. All such discriminatory legislation was abolished following recommendations by the Wiehahn Commission of Inquiry in 1979. The Labour Relations Act (1995) prohibited discrimination based on the grounds of race or gender, and if discrimination occurred, it was deemed to be an unfair labour practice.

\section{Representation of designated groups in South Africa and Canada}


South African employers are required to group employees into six occupational levels, ranging from 'top management' to 'unskilled.' Canadian employers, on the other hand, are required to group employees into fourteen occupational levels ranging from 'senior managers' to 'other manual workers.' Table 3 outlines upper management and professional/middle management in both countries from 1987 to 2007. Because the South African Employment Equity Act was passed by the Parliament in 1998, no data are available for 1987. The Canadian Employment Equity Act came into effect in 1986, and as a result, we provide a comparison of representation of these groups from 1987 to 2007 for upper management and professional/middle management positions.

Insert Table 3 about here

\section{Upper management in South Africa and Canada}

As Table 3 shows, Blacks (a term which includes African Blacks, Coloureds and Indians) represented $30.6 \%$ of top and senior managers in South Africa, which exposes the problem that Blacks are highly underrepresented compared to their workforce availability. On the other hand, Whites represented more than five times their availability (in relation to Blacks in top and senior management), even though Whites only account for $9.2 \%$ of the South African population. Although there has been an upward trend of Black representation at upper management levels, Black representation was almost three times lower than their workforce availability. The section to follow on developments in employment equity illustrates some reasons why Black representation is not on par with their availability in the workforce.

Table 3 illustrates that Canadian women, visible minorities and Aboriginal people are underrepresented compared to their availability, while the number of persons with disabilities at upper management levels is consistent with their availability. Although there still remain gaps at 
the upper management level for all groups except for persons with disabilities, the twenty-year trend for each designated group has been positive, with an upward trend in representation for each group as indicated by the change in representation rates.

\section{Professional and middle management in South Africa and Canada}

Blacks represented $41.3 \%$ of all employees at the professional and middle management level in 2007. Consistent with their overrepresentation at the upper management level, the representation of Whites at this level was approximately five times higher than their workforce availability. White representation at the professional/mid-management level has increased since the implementation of employment equity measures, while there has been a proportionate decrease for Blacks at this level. The decrease in Blacks at the professional/middle management level is cause for concern especially given that the employment equity legislation has been in place for almost 10 years at this point.

Canadian data show that women, persons with disabilities and Aboriginals are underrepresented relative to their availability, while visible minorities are overrepresented compared to their workforce availability. Unlike the South African trends, representation levels of each group have increased since employment equity legislation was established, which suggests that some progress has been made.

\section{South African and Canadian data on recruitment and promotions}

The representation of designated groups at higher occupational levels does not give us a complete understanding of the effects of employment equity. Another way to analyze the progress made from employment equity is to look at the proportion of groups recruited and promoted at each occupational level. Table 4 shows the change in the number of recruits for each occupational group from 2003 to 2007. Despite the efforts of the employment equity legislation, African employees are largely recruited at lower occupational levels (e.g., unskilled), whereas 
White males are mostly recruited at top and mid management occupational levels. The recruitment of Whites at the top management level is almost twice that of Africans. This finding is especially important given that Africans are the majority group. Indians have seen the most significant improvement of being recruited at the upper management level, with a slight increase in recruitment at both the professional/mid-management and skilled levels. The recruitment of Coloureds as upper-level managers has slightly increased, but other levels have experienced a marked drop in recruitment (e.g., skilled occupations).

In terms of promotions, Table 5 demonstrates that White employees were more likely to be promoted at upper management levels than any other designated group. Black employees have seen little change in promotions at higher occupational levels. The most marked changes have occurred at skilled/intermediate occupational levels, where there has been a $20 \%$ increase of the promotion of Africans, while at the same time $22 \%$ fewer Coloureds were promoted. The same finding holds true for professional/middle-management and semi-skilled levels where on the one hand, the promotion of Africans has increased while in stark contrast, Coloureds were less likely to be promoted. Indians had the most consistent increase in promotions at all occupational levels.

Insert Table 4 about here

As shown by Table 4, few members of the designated groups are recruited at the top management occupational level in comparison to their representation in the Canadian population, with women especially underrepresented at this level. This finding is consistent for the promotion of the designated groups. Although there is a positive upward trend at most occupational levels, the progress has been slow and steady. 
Insert Table 5 about here

\section{Evaluation of employment equity developments}

With legislative advancement, the legacy of workplace discrimination against designated groups is systematically being eroded, albeit very slowly. According to the Commission on Gender Equality (1999), women constituted the major segment of the South African population, but accounted for only one-third of the labour force, and were mainly concentrated in service, retail, and manufacturing sectors. Across all sectors, women mainly occupied jobs associated with stereotyped domestic roles; thus, gender equality within the workplace, according to the Commission on Gender Equality, was underpinned by job segregation and perceived roles associated with women (Commission on Gender Equality, 1999). Although progress has been slow, it must be kept in mind that the Employment Equity Act in South Africa has only been in effect for 12 years. The legacy of apartheid will take some time to overcome.

Although some progress has been made in enhancing racial and gender representation in the South African workplace, the progress has been more incremental than transformational. The data show that the upward mobility of black managers and women has been limited. There is a concentration of managerial control through a system of interlocking directorates where the same person(s) serves on the boards of several corporations. Noteworthy however, this 'interlocking directorate class' is becoming more multi-racial in its composition. South Africa's re-entry into the international business community has increased global awareness about its relative competitiveness in the manufacturing and services sectors. Recently, statutory and governmental tender requirements have been towards employment equity and diversity at all levels. Several black directors have been appointed to boards of directors. Although less than $18 \%$ of South Africa's company directors are black or women, this is likely to change 
significantly given the legislative interventions for broad based black economic empowerment, which includes shared ownership and requires compliance with sector charters.

An explanation for this incremental progress may be that employment equity is not only a supply-side matter, but one which relates to persisting issues (Booyson, 2007). These prevailing issues include White-male oriented organizational cultures, lack of communication and shared understanding of employment equity, low leadership commitment, and inconsistent implementations of employment equity measures. According to institutional theory, these issues are so prevalent that organizations follow mimetic forces of imitating each other to follow longestablished norms of promoting discrimination.

Booyson (2007) also acknowledges the role of White employees' fear of displacement and lack of meaningful engagement. Kelly, Wale, Soudien, and Steyn's (2007) critical analysis can be applied to understanding the debate surrounding workplace changes or transformation that pertain to diversity. Three dimensions are considered in this regard: categories of difference, engagement of difference, and sites of change. Dominant paradigms often do not adequately consider the alignment of dimensions, providing for deep transformative practice. The discourse on diversity has followed various frameworks (e.g., Thomas and Ely, 1996), which refer to the discrimination and fairness perspective (arguably the dominant paradigm in South African discourse), an access and legitimacy perspective, and a learning and effectiveness or transformative perspective. Nkomo and Stewart (2006) note that the 'business case' for diversity (and employment equity) is premised on a need to make the politically overt practices of employment equity more palatable for White male mangers by stressing their 'economically' viability premise. However, 'effective' organizational change would need to move beyond legislative compliance which more often than not, elicits a begrudging sense of compliance rather than a deeper commitment and organizational learning. 
Booysen (2007) and Moleke (2006) seek a more inclusive culture in which organizations value diversity, support employment practices, develop an integrated and holistic human resource development and retention strategy, and identify and manage effective talent. To be effective, employment equity has to be supported by coherent human resource development priorities through the implementation of skills development legislation and changes in organizational cultures. This support is vital at both public policy and organizational levels. Prioritizing human resource skills and competency development and education is fundamental due to a serious skills shortage in priority skills in the South African economy, in which the shortage has grown at approximately $5 \%$ over the past five years.

The government has recognized this reality by enacting the Broad Based Black Economic Empowerment (BBBEE) Act of 2003. Since the enactment of the BBBEE Act, the economy has experienced enhanced economic growth in the private sector, and the state has increased the participation of Black people in the mainstream economy. In fact, the government as an employer accounts for most of the progress in racial representation and the advancement of Black people in the labour market (Moleke, 2006). Despite this progress, disparities still remain in the distribution of Black people at different skills levels. BBBEE measures have sought to address these disparities by having a national integrated human resource development strategy, legislated de-racialization of business ownership in the private sector, national targets that include land distribution and ownership, and equity participation in economic sectors. These overall measures, along with the progress in implementing employment equity, will greatly improve the chances of majority Blacks to have their just share in the South African economy. BBBEE codes and scorecards by the Department of Trade and Industry recommend that employers emphasize several elements of skills development and seek to economically empower 
designated groups through ownership in shares and purchase interventions. However, to date, the impact of this development has been an uneven process with the majority not benefiting directly.

The South African government has also initiated an important skills development process through ASGISA (Accelerated Skills and Growth Initiative) and JIPSA (Joint Initiative on Priority Skills Acquisition), which focuses on identifying and funding priority skills formation. These initiatives occur in the context of South Africa's accelerated growth and priority skills plans. Transformation and employment equity developments have begun to economically empower the majority of Black designated groups in key priority areas, such as engineering and health care, but skill retention in scarce areas remains a critical problem. The retention of skills is a problem because of 'pull factors' pertaining to the current mobility of talent in global labour markets and 'push factors' including violent crime (Horwitz, 2007). Supply side outputs from universities of Black engineering and business graduates are unsatisfactory. Degree completion rates by Black students are less than half that of the White completion rate, negating the gains made in black enrollment access and equity. Lower completion rates among Black students even occur in institutions where the enrollment of first-year Black students exceeds that of White students (Scott, Yeld, \& Henry, 2007). With some exceptions, several of the sector training authorities (e.g., SETAS) appear not to be meeting their statutory skills development mandate, in spite of sufficient funding, and are currently being reviewed by the South African government with a view to integrating some of them and enhancing operational and delivery efficiencies. Employment equity and skills development are interrelated and interdependent processes because employment equity cannot effectively occur without skills formation.

In Canada, even though employment equity has been present for more than 20 years, employment equity data show that visible minorities and women still face glass ceilings in higher 
level occupations. Based on our evaluations of employment equity developments, the following need serious attention: (1) increased and vigorous enforcement by the Canadian Human Rights Commission (CHRC) and (2) more focus on occupational inequities. Organizations must create a climate of acceptance and tolerance by sensitizing top management to the need to eliminate glass ceilings for both women and visible minorities. Furthermore, (3) there ought to be more focus on industrial sector differences (e.g., communication and transportation sectors), where women and visible minorities are underrepresented. Increased vigorous monitoring of the under-representation of women and visible minorities is needed in smaller companies by the CHRC (Jain \& Lawler, 2004). This recommendation is consistent with April and Dreyer (2007), who conclude from qualitative research findings that female executives are affected by structural inequalities, such as glass ceilings, power and organization-gendered systems, accompanying misogynistic cultures and behaviours, and work-life balance and career life-cycle factors.

Monitoring is also necessary in both jurisdictions for employment equity programs to effect change. Regular evaluations can indicate the amount of progress made towards set objectives and the need for suitable corrective action or adjustment. These evaluations would also encourage organizations to respond to regulative forces according to institutional theory. Failure to respond to the forces puts organizations at risk of legal sanctions. Monitoring should include: periodic reports of progress toward meeting goals, flow information on staffing, and adequate systems for human resource information management. Monitoring requires a systematic evaluation of the current environment and practices, in addition to the development of employment equity indicators combined into a scorecard in order to evaluate progress. Research indicates that employment equity programs are more likely to succeed when line managers are an integral component of the planning and implementation of programs and are held accountable for 
the outcomes (Jain \& Hackett, 1989; Jain et al., 2003). In this way, the assessment of line managers' performance and link to bonuses, salary increases, or promotions, facilitates the acceptance and adoption of employment equity throughout organizations.

Our conclusion is that while progress is being made in both countries as a result of the regulative forces of legislation, it is too slow in the case of the case of some designated groups, especially Africans in South Africa, Aboriginals in Canada, and persons with disabilities in both countries. Governments in both countries need to make sustained efforts to make the legislation effective. Institutional theory shows that legislation is unlikely to act as a regulative force and shape how organizations respond to employment equity without increased enforcement.

In South Africa, labour inspectors need to be given greater latitude and more flexibility to carry out auditing responsibilities (Jain, Mbabane, \& Horwitz, 2005) Governments also need to be more proactive in educating employers and enforcing the legislation. In Canada, increased enforcement by the Canadian Human Rights Commission (CHRC) is necessary. In our view, the CHRC needs to pay more attention to monitoring and enforcing employment equity in large firms, since it cannot be taken for granted that larger firms do well overall in developments in employment equity. As shown by our results from a recent study, smaller firms made more progress in the employment equity of females than larger firms (Jain, Lawler, Bai, \& Lee, 2010). It may be necessary for the $\mathrm{CHRC}$ to examine the particular occupational groups within larger companies where employment equity is either low or non-existent relative to the workforce availability of designated groups. It is therefore clear that increased and vigorous enforcement of the employment equity act for the designated groups, especially for persons with disabilities and Aboriginal persons, is necessary by the Canadian Human Rights Commission. The Human Resources \& Skills Development Canada (HRSDC) may also play a more active role in developing labour market policies to correct this imbalance. 
Following Kelly et al. (2007), we note that comparative evaluations of employment equity systems, such as Canada and South Africa, have descriptive and instructive value, especially in terms of institutional or regulatory perspectives but have inherent limitations, given the different historical, socio-cultural, and power dynamics that characterize the social fabric of each society and its organizations. Comparative evaluations also are limited by the essentially different 'space and time' dynamics of evolving and changing social systems. In spite of these limitations, there is still value in comparative evaluations in order to facilitate the identification of propositions to further eliminate unfair employment discrimination. 


\section{References}

Agocs, C., \& Burr, C. (1996), 'Employment Equity, Affirmative Action and Managing Diversity: Assessing the Differences', International Journal of Manpower, 17(4/5), 3045.

April, K., \& Dreyer, S. (2007), 'Gender Unplugged in the Executive Boardroom: The Paradigm Shift', Effective Executive, 62-77.

Black Economic Empowerment Commission (2001), Black Economic Empowerment Commission Report, Johannesburg, SA: Skotaville Press.

Blum, T.C., Fields, D.L., \& Goodman, J.S. (1994), 'Organization-Level Determinants of Women in Management', Academy of Management Journal, 37(2), 241-268.

Booysen, L. (2007), 'Barriers to Employment Equity Implementation and Retention of Blacks in Management in South Africa', South African Journal of Labour Relations, 31(1), 47-70.

Commission on Gender Equality (1999), Survey of Employers Regarding Affirmative Action Policies and Practices: Gender and the Private Sector. Pretoria, SA: Author.

Department of Labour (2007), 'Employment Equity: Labour Minister Considers Court Action', www.labour.gov.za.

Department of Trade \& Industry (2004), Broad Based Economic Empowerment Act, 2003. Pretoria, SA: Government Gazette.

DiMaggio, P.J., \& Powell W.W. (1991), 'The Iron Cage Revisited: Institutional Isomorphism and Collective Rationality in Organizational Fields', in The New Institutionalism in Organizational Analysis, eds. W.W. Powell \& P.J. DiMaggio, Chicago, IL: University of Chicago Press, pp. 241-268.

Horwitz, F.M., Jain, H., \& Mbabane, L. (2005), 'Trade Union Consultation by Employers Under 
Employment Equity Legislation', South African Journal of Labour Relations, 29(2-4), 4-31.

Horwitz, F.M. (2007), 'Myths and Realities: Is the Skills Shortage about Demand and Supply or Effective Retention?' Convergence, 8(4), 48-51.

Human Resources and Social Development Canada (2008), Employment Equity Act: Annual Report 2008, Gatineau, QC: Author.

Immen, W. (2007, June 29), 'Minorities Still See Barriers in Way to Top', Globe \& Mail, p.C1.

Jaffee, D. (2001), Organization Theory: Tension and Change, Boston: McGraw-Hill.

Jain, H.C., \& Hackett, R. (1989), 'Measuring Effectiveness of Employment Equity Programs in Canada: Public Policy and a Survey', Canadian Public Policy, 15, 189-204.

Jain, H.C., Verma, A., \& Zinni, D. (2003), Union Consultation by Employers and Employment Equity, A Study submitted to Human Resources and Social Development Canada.

Jain, H.C., \& Lawler, J. (2004), 'Visible minorities under the Canadian (federal) employment Equity Act: 1987-1999', Relations Industrielles/Industrial Relations, 59(3), 585-611.

Jain, H.C., Lawler, J., Bai, B., \& Lee, E.K. (2010), ‘Effectiveness of Canada’s employment equity legislation for women (1997-2004): Implications for policy makers.' Relations Industrielles/Industrial Relations, 65(2), 304-329.

Jain, H.C., Mbabane, L, \& Horwitz, F.M. (2005), 'Trade union consultation by employers under employment equity legislation.' Paper delivered at the 4th Regional African Congress of the International Industrial Relations Association (IIRA), Mauritius.

Jain, H.C., Sloane, P.J., \& Horwitz, F.M. (2003), Employment Equity and Affirmative Action: An International Comparison, Armonk: NY: M.E. Sharpe.

Kelly, C., Wale, K., Soudien, C., \& Steyn, M. (2007), 'Aligning Diversity 'Rubik Cube': 
Conceptualizing Transformative Practice', South African Journal of Labour Relations, $31(2), 10-31$.

Mbabane, L. (2007), ‘Broad Based Black Economic Empowerment: A Human Capital Development Approach', unpublished Ph.D. dissertation, University of Cape Town, Graduate School of Business.

Meyer, J.W., \& Rowan, B. (1991), 'Institutionalized Organizations: Formal Structure as Myth and Ceremony', in The new institutionalism in organizational analysis, eds. W.W. Powell \& P.J. DiMaggio, Chicago, IL: University of Chicago Press, pp. 41-62.

Moleke, P. (2006), 'After 10 Years of Employment Equity, It's Still Business as Usual', HSRC Review, 4(1), 4-5.

Nkomo, S.M., \& Stewart, M. (2006), 'Diverse Identities in Organizations', in Handbook of Organizational Studies, eds. S. Clegg, C. Hardy, \& W. Nord, London, UK: Sage, pp. $520-540$.

Oliver, C. (1991), 'Strategic Responses to Institutional Processes', Academy of Management, 16(1), 145-179.

Scott, I., Yeld, N., \& Hendry, J. (2007), A Case for Improving Teaching and Learning in South African Higher Education (Higher Education Monitor No. 6). Pretoria, South Africa: Council on Higher Education.

Scott, W.R. (1998), Organizations: Rational, Natural, and Open Systems, Upper Saddle River, NJ: Prentice Hall.

South African Institute of Race Relations (2008), 'Social indicators', Fast Facts, 1, 2-7.

Statistics Canada (2001), Census of Canada, Ottawa, ON: Statistics Canada

Thomas, D.A., \& Ely, R.D. (1996), 'Making Differences Matter: A New Paradigm for Managing Diversity', Harvard Business Review, October, 79-90. 
Table 1: Common Features of Employment Equity Legislations in Canada and South Africa

\begin{tabular}{|c|c|}
\hline Canada (1995) & South Africa (1998) \\
\hline $\begin{array}{l}\text { 1. Designated Groups: } \\
\text { Women } \\
\text { Aboriginal People } \\
\text { Persons with Disabilities } \\
\text { Visible Minorities (Racial Minorities) }\end{array}$ & $\begin{array}{l}\text { 1. Designated Groups } \\
\text { Women } \\
\text { Persons with Disabilities } \\
\text { Blacks include: } \\
\text { African Blacks (Majority Population) } \\
\text { Coloureds } \\
\text { Indians }\end{array}$ \\
\hline $\begin{array}{l}\text { 2. Identify and eliminate job barriers by } \\
\text { undertaking a thorough review of an } \\
\text { employer's staffing policies and practices. } \\
\text { These practices might include word of mouth } \\
\text { recruitment, credentialism, height and weight } \\
\text { restrictions that are unrelated to job } \\
\text { performance, inflated job experience, possible } \\
\text { bias in psychological tests, discrimination in } \\
\text { job interviews, and glass ceilings in } \\
\text { promotion opportunities. One of the critical } \\
\text { prerequisites to an effective employment } \\
\text { equity program is the identification and } \\
\text { elimination of unfair discriminatory barriers } \\
\text { to employment opportunities. Such } \\
\text { discriminatory barriers are insidious, having } \\
\text { become "patterns of behaviour that are part of } \\
\text { the social and administrative structures and } \\
\text { culture of the workplace, and that create or } \\
\text { perpetuate a position of relative disadvantage } \\
\text { for some groups (and advantage for others), or } \\
\text { for individuals, on the basis of their group } \\
\text { identity" (Agocs \& Burr, 1996). }\end{array}$ & $\begin{array}{l}\text { 2. Identify and eliminate job barriers by } \\
\text { undertaking a thorough review of an } \\
\text { employer's staffing policies and practices. } \\
\text { These practices might include word of mouth } \\
\text { recruitment, credentialism, height and weight } \\
\text { restrictions that are unrelated to job } \\
\text { performance, inflated job experience, possible } \\
\text { bias in psychological tests, discrimination in } \\
\text { job interviews, and glass ceilings in } \\
\text { promotion opportunities. One of the critical } \\
\text { prerequisites to an effective employment } \\
\text { equity program is the identification and } \\
\text { elimination of unfair discriminatory barriers } \\
\text { to employment opportunities. Such } \\
\text { discriminatory barriers are insidious, having } \\
\text { become "patterns of behaviour that are part of } \\
\text { the social and administrative structures and } \\
\text { culture of the workplace, and that create or } \\
\text { perpetuate a position of relative disadvantage } \\
\text { for some groups (and advantage for others), or } \\
\text { for individuals, on the basis of their group } \\
\text { identity" (Agocs \& Burr, 1996). }\end{array}$ \\
\hline $\begin{array}{l}\text { 3. Employers must have Employment Equity } \\
\text { plans which include: } \\
\text { a) Positive measures which involve } \\
\text { remedying the effects of past discrimination } \\
\text { through pro-active recruitment, selection, } \\
\text { training, and promotion of historically } \\
\text { disadvantaged individuals. } \\
\text { b) Reasonable accommodation measures such } \\
\text { as accommodation of religious observances, } \\
\text { offering flexible working hours, maternity } \\
\text { leave, washroom facilities for women, and }\end{array}$ & $\begin{array}{l}\text { 3.Employers must have Employment Equity } \\
\text { plans which include: } \\
\text { a) Positive measures which involve } \\
\text { remedying the effects of past discrimination } \\
\text { through pro-active recruitment, selection, } \\
\text { training, and promotion of historically } \\
\text { disadvantaged individuals. } \\
\text { b) Reasonable accommodation measures such } \\
\text { as accommodation of religious observances, } \\
\text { offering flexible working hours, maternity } \\
\text { leave, washroom facilities for women, and }\end{array}$ \\
\hline
\end{tabular}


developing and enforcing racial and sexual harassment policies.

c) Internal and external workforce analysis such as stock and flow analysis of its workforce using Canadian Census labour force figures (i.e., workforce availability rates) by industrial and occupational levels. d) Measures to recruit, retain, train, develop, and promote qualified designated groups throughout the organization. Good practices include proactive efforts to recruit and train designated group members, ensuring that recruiting teams are represented by members of designated groups, providing recruiting material in several languages, and introducing mentoring programs. Other good practices include offering special measures in the form of flex-time, internal and external communications, work sharing, child-care, and educational assistance. These practices have been noted by the Annual Equal Employment Equity Reports by the HRSDC.

4. Employers are required to consult with employee representatives or bargaining agents in the case of unionized employees.

Employers are also required to provide information on their equity plans to all employees. While employee participation is well researched internationally, there is limited research on its specific application in the area of employment equity. This is especially true in the case of the federal Employment Equity Act. In a study commissioned by HRSDC, Jain,Verma, and Zinni (2004) found employers, in general, do not consult with unions on EE. The researchers contacted trade unions and employers. The researchers used questionnaires, content analysis of public documentation submitted by the respective employers to the HRSDC in their annual reports, and discussions with the auditors of the Canadian Human Rights Commission. Only a select few of the employers actually worked with their unions to make their employment equity programs successful (Air developing and enforcing racial and sexual harassment policies.

c) Internal and external workforce analysis such as stock and flow analysis of its workforce using South African "economically active population" figures in all occupational categories and levels.

d) Measures to recruit, retain, train, develop, and promote qualified designated groups throughout the organization. Good practices include proactive efforts to recruit and train designated group members, ensuring that recruiting teams are represented by members of designated groups, providing recruiting material and introducing mentoring programs. Other good practices include offering special measures in the form of flex-time, internal and external communications, work sharing, childcare, and educational assistance. These practices have been reported annually by the South African employment equity reports under 'Good Practices"

4. Employers are required to consult with employee representatives or bargaining agents in the case of unionized employees.

Employers are also required to provide information on their equity plans to all employees. While employee participation is well researched internationally, there is limited research on its specific application in the area of employment equity, particularly as it applies in the South African labour market. Horwitz, Jain, and Mbabane (2005) found that, although incremental progress has been made in enhancing racial and gender representation in the South African workplace, employment equity efforts were not strongly supported by employer consultation with trade unions. Union participation in equity planning appears to be largely 'information giving' or at a "rudimentary consultation level," with inputs being sought from representatives, but little evidence of workplace partnership in employment equity planning and human resource development. Limited union 
Canada Regional, Bell Canada, Telus, Canada Post, Canadian Pacific, and Hudson General Aviation). It is a select group of companies from various industries., and not a particular industry.

Interviews with the auditors revealed there are various times when unions are not involved in the employment equity process either because of employer-union negotiations or strikes. However, the CHRC auditors felt there is nothing that the auditors can do to enforce the employer to include the union and there are no financial penalties for failure to comply. The Employment Equity Act does not provide for financial penalties for non compliance and the auditors are not granted any power to enforce the Act. The Act does not allow the union to share any responsibility for the employment equity plan. The union must be consulted, but this can actually occur at the end of the process before the actual audit if the company so desired.

5. Numerical goals and timetables According to externally available figures and devise strategies to address underrepresentation of designated groups in all occupational categories and levels. Numerical goals and timetables are instrumental in facilitating the effectiveness of employment equity programs. Employment equity programs should focus on all the designated groups (not just one) and specify goals and timetables that range from one to five years. Leonard (1985) has shown that progress is achieved through the creation of definite employment equity targets.

6. Employment equity does not require employers to adopt measures that might cause undue hardship. In Canada, there is no requirement to hire or promote unqualified designated individuals or to create new positions in workforces. In South Africa, an employer is prohibited to make any decision partnership occurs in South Africa in spite of Section 16 of the Employment Equity Act that requires employers to take reasonable steps to consult and reach agreements with employee representatives or bargaining agents.
5. Numerical goals and timetables

According to externally available figures and devise strategies to address underrepresentation of designated groups in all occupational categories and levels via Economically Active Population. Numerical goals and timetables are instrumental in facilitating the effectiveness of employment equity programs. Employment equity programs should focus on all the designated groups (not just one) and specify goals and timetables that range from one to five years. Leonard (1985) has shown that progress is achieved through the creation of definite employment equity targets.

\section{Employment equity does not require} employers to adopt measures that might cause undue hardship. In South Africa, an employer is prohibited to make any decision that will establish an absolute barrier to the prospective or continued employment of non-designated groups (e.g., White males). 


\begin{tabular}{|c|c|}
\hline $\begin{array}{l}\text { that will establish an absolute barrier to the } \\
\text { prospective or continued employment of non- } \\
\text { designated groups (e.g., White males). }\end{array}$ & \\
\hline $\begin{array}{l}\text { 7. The Employment Equity Act requires } \\
\text { employers to keep records relating to } \\
\text { employee 'stock and flow'. Records pertain to } \\
\text { data on workforce profiles in terms of race, } \\
\text { gender, and disability level, as well as flow } \\
\text { data, such as labour turnover and promotions. } \\
\text { Arguably, record keeping is simply good } \\
\text { human resource management and planning } \\
\text { practice, notwithstanding the legislative } \\
\text { requirements to do so. }\end{array}$ & $\begin{array}{l}\text { 7. The Employment Equity Act requires } \\
\text { employers to keep records relating to } \\
\text { employee 'stock and flow'. Records pertain to } \\
\text { data on workforce profiles in terms of race, } \\
\text { gender, disability and level, as well as flow } \\
\text { data, such as labour turnover and promotions. }\end{array}$ \\
\hline $\begin{array}{l}\text { 8. Employment Equity plans for the short and } \\
\text { long term. } \\
\text { In Canada, short-term plans are from one to } \\
\text { three years and long term plans are from three } \\
\text { to five years. }\end{array}$ & $\begin{array}{l}\text { 8. Employment Equity plans for the short and } \\
\text { long term. } \\
\text { In South Africa, the requirement is one to five } \\
\text { years. }\end{array}$ \\
\hline
\end{tabular}


Table 2: Distribution of designated group members in Canada and South Africa

\begin{tabular}{|c|c|c|c|}
\hline & $1996(\%)$ & $2001(\%)$ & $2006(\%)$ \\
\hline \multicolumn{4}{|l|}{ CANADA } \\
\hline Females & 50.8 & 50.9 & 47.9 \\
\hline Persons with disabilities & 7.0 & 5.1 & 5.8 \\
\hline Visible minorities & 11.2 & 13.4 & 15.3 \\
\hline Aboriginal peoples & 2.8 & 3.3 & 3.1 \\
\hline \multicolumn{4}{|l|}{ SOUTH AFRICA } \\
\hline Females & 51.9 & 52.2 & 50.8 \\
\hline Persons with disabilities & 6.5 & 5.9 & $\mathrm{n} / \mathrm{a}$ \\
\hline Blacks & 88.2 & 90.4 & 90.9 \\
\hline Africans & 76.7 & 79.0 & 79.5 \\
\hline Coloureds & 8.9 & 8.9 & 8.9 \\
\hline Indians & 2.6 & 2.5 & 2.5 \\
\hline Whites & 10.9 & 9.6 & 9.2 \\
\hline
\end{tabular}


Table 3: Comparison of representation at higher occupational levels within South African and Canadian workplaces by designated and occupational groups

\begin{tabular}{|c|c|c|c|c|c|c|c|c|c|c|c|c|}
\hline \multirow{2}{*}{$\begin{array}{l}\text { Designated } \\
\text { Group }\end{array}$} & \multicolumn{4}{|c|}{$\overline{\text { Upper Management }}$} & \multirow{2}{*}{$\begin{array}{c}\text { Change } \\
(\%)\end{array}$} & \multirow{2}{*}{$\begin{array}{c}\text { Availability } \\
2001(\%)\end{array}$} & \multicolumn{4}{|c|}{ "Professionals/mid-management } & \multirow{2}{*}{$\begin{array}{c}\text { Change } \\
(\%)\end{array}$} & \multirow{2}{*}{$\begin{array}{c}\text { Availability } \\
2001(\%)\end{array}$} \\
\hline & $1987(\%)$ & $2001(\%)$ & $2005(\%)$ & $2007(\%)$ & & & $1987(\%)$ & $2001(\%)$ & $2005(\%)$ & $2007(\%)$ & & \\
\hline \multicolumn{13}{|l|}{ CANADA } \\
\hline Women & 4.8 & 19.6 & 20.9 & 21.9 & 17.1 & 25.1 & 36.1 & 43.5 & 44.2 & 44.2 & 8.1 & 45.3 \\
\hline $\begin{array}{l}\text { Visible } \\
\text { minorities }\end{array}$ & 2.1 & 3.7 & 5.2 & 5.4 & 3.3 & 8.2 & 7.4 & 12.7 & 15.7 & 17.9 & 10.5 & 12.8 \\
\hline $\begin{array}{l}\text { Persons with } \\
\text { disabilities }\end{array}$ & 1.6 & 1.9 & 2.5 & 2.6 & 1.0 & 2.1 & 1.5 & 1.9 & 2.4 & 2.5 & 1.0 & 3.6 \\
\hline $\begin{array}{l}\text { Aboriginal } \\
\text { peoples }\end{array}$ & 0.2 & 0.5 & 0.7 & 0.9 & 0.7 & 2.5 & 0.4 & 0.9 & 1.0 & 1.1 & 0.7 & 1.5 \\
\hline \multicolumn{13}{|c|}{ SOUTH AFRICA } \\
\hline Blacks & $\mathrm{n} / \mathrm{a}$ & 22.1 & 27.4 & 30.6 & 8.5 & 87.9 & $\mathrm{n} / \mathrm{a}$ & 50.2 & 38.7 & 41.3 & -8.9 & 87.9 \\
\hline Africans & $\mathrm{n} / \mathrm{a}$ & 8.9 & 16.2 & 18.5 & 9.6 & 74.8 & $\mathrm{n} / \mathrm{a}$ & 39.7 & 21.5 & 24.1 & -15.6 & 74.8 \\
\hline Coloureds & $\mathrm{n} / \mathrm{a}$ & 8.9 & 4.9 & 5.0 & -3.9 & 10.3 & $\mathrm{n} / \mathrm{a}$ & 6.0 & 9.3 & 8.5 & 2.5 & 10.3 \\
\hline Indians & $\mathrm{n} / \mathrm{a}$ & 4.3 & 6.3 & 7.2 & 2.9 & 2.8 & $\mathrm{n} / \mathrm{a}$ & 4.4 & 7.9 & 8.7 & 4.3 & 2.8 \\
\hline Whites & $\mathrm{n} / \mathrm{a}$ & 77.9 & 72.5 & 66.7 & -11.2 & 12.1 & $\mathrm{n} / \mathrm{a}$ & 49.9 & 61.3 & 56.9 & 7.0 & 12.1 \\
\hline
\end{tabular}

Source: Adapted from South African Employment Equity Reports (2003 and 2007/2008) and Canadian Employment Equity Reports (1997, 2002, 2007, and 2008).

Note: South African data include persons with disabilities. 
Table 4: Comparison of recruits within South African workplaces and within Canadian federally regulated private sector and crown corporations by designated group and occupational group

\begin{tabular}{|c|c|c|c|c|c|c|c|c|c|c|c|c|c|c|c|}
\hline \multirow[t]{2}{*}{ Designated Group } & \multicolumn{2}{|c|}{$\begin{array}{c}\text { Upper } \\
\text { Management(\%) }\end{array}$} & \multirow{2}{*}{$\begin{array}{c}\text { Change } \\
(\%)\end{array}$} & \multicolumn{2}{|c|}{$\begin{array}{c}\text { Professionals/mid- } \\
\text { management(\%) }\end{array}$} & \multirow{2}{*}{$\begin{array}{c}\text { Change } \\
(\%)\end{array}$} & \multicolumn{2}{|c|}{$\begin{array}{c}\text { Skilled and } \\
\text { intermediate(\%) }\end{array}$} & \multirow{2}{*}{$\begin{array}{c}\text { Change } \\
(\%)\end{array}$} & \multicolumn{2}{|c|}{$\begin{array}{c}\text { Semi- } \\
\text { skilled(\%) }\end{array}$} & \multirow{2}{*}{$\begin{array}{c}\text { Change } \\
(\%)\end{array}$} & \multicolumn{2}{|c|}{ Unskilled (\%) } & \multirow{2}{*}{$\begin{array}{r}\text { Char } \\
(\% \\
\end{array}$} \\
\hline & 2003 & 2007 & & 2003 & 2007 & & 2003 & 2007 & & 2003 & 2007 & & 2003 & 2007 & \\
\hline \multicolumn{16}{|l|}{ "CANADA } \\
\hline Women & 20.9 & 20.4 & -0.5 & 39.5 & 38.7 & -0.8 & 55.5 & 54.0 & -1.5 & 10.9 & 12.7 & 1.8 & 22.5 & 24.1 & $\overline{1 . t}$ \\
\hline Visible minorities & 2.5 & 5.8 & 3.3 & 11.9 & 17.2 & 5.3 & 13.4 & 17.0 & 3.6 & 13.6 & 14.2 & 0.6 & 9.5 & 21.4 & 11. \\
\hline $\begin{array}{l}\text { Persons with } \\
\text { disabilities }\end{array}$ & 0.9 & 3.1 & 2.2 & 1.0 & 1.3 & 0.3 & 1.2 & 1.8 & 0.6 & 1.0 & 1.1 & 0.1 & 0.6 & 0.5 & -0 . \\
\hline Aboriginal peoples & 0.3 & 1.0 & 0.7 & 1.1 & 1.2 & 0.1 & 1.9 & 2.1 & 0.2 & 2.5 & 2.8 & 0.3 & 2.3 & 2.1 & -0. \\
\hline \multicolumn{16}{|l|}{ SOUTH AFRICA } \\
\hline Blacks & 78.7 & 40.6 & -38.1 & 46.9 & 49.3 & 2.4 & 60.5 & 62.6 & 2.1 & 82.5 & 87.3 & 4.8 & 96.5 & 96.1 & $\overline{-0}$ \\
\hline Africans & 72.6 & 25.9 & -46.7 & 27.7 & 31.0 & 3.3 & 34.4 & 43.2 & 8.8 & 56.9 & 67.1 & 10.2 & 81.8 & 81.4 & -0 \\
\hline Coloureds & 4.1 & 6.8 & 2.7 & 10.1 & 8.6 & -1.5 & 19.0 & 11.8 & -7.2 & 19.5 & 15.2 & -4.3 & 13.1 & 13.3 & $0 . \dot{z}$ \\
\hline Indians & 2.0 & 7.9 & 5.9 & 9.1 & 9.7 & 0.6 & 7.1 & 7.6 & 0.5 & 6.1 & 5.0 & -1.1 & 1.6 & 1.4 & -0. \\
\hline Whites & 22.5 & 55.2 & 32.7 & 24.4 & 48.8 & 24.4 & 39.5 & 36.0 & -3.5 & 17.4 & 10.4 & -7.0 & 3.6 & 1.7 & -1. \\
\hline
\end{tabular}

Source: Adapted from South African Employment Equity Reports (2003 and 2007/2008) and Canadian Employment Equity Reports (2004 and 2008). Note: South African data include persons with disabilities and women. Specific occupational levels from each report were collapsed into general occupational groups for comparison purposes. South Africa: Top management and senior management $=$ upper management; mid-management $=$ professionals $/ \mathrm{mid}-$ management; skilled = skilled and intermediate; semi-skilled = semi-skilled; unskilled = unskilled and other. Canada: Senior managers = upper management; middle and other managers, professionals, semi-professionals and technicians, supervisors, supervisors: crafts and trades, and administrative and senior clerical personnel $=$ professionals/mid-management; skilled sales and service personnel, skilled crafts and trades workers, clerical personnel, and intermediate sales and service personnel $=$ skilled and intermediate; semi-skilled manual workers $=$ semi-skilled; other sales and service personnel and other manual workers $=$ unskilled. 
Table 5: Comparison of promotions within South African workplaces and within Canadian federally regulated private sector and crown corporations by designated group and occupational group

\begin{tabular}{|c|c|c|c|c|c|c|c|c|c|c|c|c|c|c|c|}
\hline \multirow[t]{2}{*}{ Designated Group } & \multicolumn{2}{|c|}{$\begin{array}{c}\text { Upper } \\
\text { Management(\%) }\end{array}$} & \multirow{2}{*}{$\begin{array}{c}\text { Change } \\
(\%)\end{array}$} & \multicolumn{2}{|c|}{$\begin{array}{c}\text { Professionals/mid- } \\
\text { management( }(\%)\end{array}$} & \multirow{2}{*}{$\begin{array}{c}\text { Change } \\
(\%)\end{array}$} & \multicolumn{2}{|c|}{$\begin{array}{c}\text { Skilled and } \\
\text { intermediate(\%) }\end{array}$} & \multirow{2}{*}{$\begin{array}{c}\text { Change } \\
(\%)\end{array}$} & \multicolumn{2}{|c|}{$\begin{array}{c}\text { Semi- } \\
\text { skilled(\%) }\end{array}$} & \multirow{2}{*}{$\begin{array}{c}\text { Change } \\
(\%)\end{array}$} & \multicolumn{2}{|c|}{ Unskilled (\%) } & \multirow{2}{*}{$\begin{array}{r}\text { Char } \\
(\% \\
\end{array}$} \\
\hline & 2003 & 2007 & & 2003 & 2007 & & 2003 & 2007 & & 2003 & 2007 & & 2003 & 2007 & \\
\hline \multicolumn{16}{|l|}{ CANADA } \\
\hline Women & 26.2 & 26.2 & 0.0 & 51.6 & 51.2 & -0.4 & 59.3 & 57.9 & -1.4 & 42.2 & 12.5 & -29.7 & 23.4 & 26.3 & 2.5 \\
\hline Visible minorities & 3.1 & 7.1 & 4.0 & 16.9 & 23.2 & 6.3 & 17.2 & 22.6 & 5.4 & 11.8 & 11.9 & 0.1 & 9.4 & 11.8 & 2.4 \\
\hline $\begin{array}{l}\text { Persons with } \\
\text { disabilities }\end{array}$ & 0.8 & 2.9 & 2.1 & 1.8 & 2.1 & 0.3 & 2.0 & 2.6 & 0.6 & 2.5 & 1.6 & -0.9 & 2.3 & 1.7 & -0.1 \\
\hline Aboriginal peoples & 0.0 & 1.0 & 1.0 & 1.3 & 1.5 & 0.2 & 2.2 & 2.4 & 0.2 & 3.1 & 3.6 & 0.5 & 3.5 & 2.9 & -0.1 \\
\hline \multicolumn{16}{|l|}{ SOUTH AFRICA } \\
\hline Blacks & 38.6 & 40.0 & 1.4 & 52.4 & 53.6 & 1.2 & 71.4 & 71.6 & 0.2 & 87.4 & 90.5 & 3.1 & 98.6 & 95.4 & -3. \\
\hline Africans & 20.2 & 21.0 & 0.8 & 22.2 & 32.8 & 10.6 & 30.2 & 50.3 & 20.1 & 63.1 & 74.7 & 11.6 & 68.4 & 83.8 & 15. \\
\hline Coloureds & 8.4 & 8.1 & -0.3 & 22.4 & 10.4 & -12.0 & 36.2 & 14.2 & -22.0 & 18.3 & 12.2 & -6.1 & 28.6 & 10.1 & -18 . \\
\hline Indians & 10.0 & 10.9 & 0.9 & 7.8 & 10.4 & 2.6 & 5.0 & 7.1 & 2.1 & 6.0 & 3.6 & -2.4 & 1.6 & 1.5 & -0 \\
\hline Whites & 61.4 & 58.8 & -2.6 & 47.6 & 45.6 & -2.0 & 28.7 & 27.8 & -0.9 & 12.5 & 7.0 & -5.5 & 1.4 & 1.4 & $0 . \mathrm{C}$ \\
\hline
\end{tabular}

Source: Adapted from South African Employment Equity Reports (2003 and 2007/2008) and Canadian Employment Equity Reports (2004 and 2008).

Note: South African data include persons with disabilities and women. Specific occupational levels from each report were collapsed into general occupational groups for comparison purposes. South Africa: Top management and senior management $=$ upper management; mid-management $=$ professionals/midmanagement; skilled = skilled and intermediate; semi-skilled $=$ semi-skilled; unskilled $=$ unskilled and other. Canada: Senior managers $=$ upper management; middle and other managers, professionals, semi-professionals and technicians, supervisors, supervisors: crafts and trades, and administrative and senior clerical personnel = professionals/mid-management; skilled sales and service personnel, skilled crafts and trades workers, clerical personnel, and intermediate sales and service personnel $=$ skilled and intermediate; semi-skilled manual workers $=$ semi-skilled; other sales and service personnel and other manual workers $=$ unskilled. 